\title{
Calculation of Uncertainties in Influence Quantities in Biological Essays
}

\author{
Pierre Morel $^{\text {* }}$, Tatiana Langbeck de Arruda ${ }^{2}$ and Maria Beatriz C. Bohrer-Morel ${ }^{3}$ \\ ${ }^{1}$ Consultant; PAJ MOREL; Av. Jabirú, 252; Vista Alegre; 13280-000; pierre@uol.com.br; Vinhedo - SP - Brasil. \\ ${ }^{2}$ Environmental Impact Analysis Laboratory; Rhodia Brasil Ltda; Paulínia - SP - Brasil. ${ }^{3}$ Ecotoxicology \\ Laboratory; Chemistry and Environment Center; Nuclear and Energy Research Institute - IPEN; São Paulo - SP - \\ Brasil
}

\begin{abstract}
Due to the need of showing the reliability of results from biological essays, such as in health and environmental areas, laboratories have been implementing quality systems, particularly ABNT NBR ISO/IEC 17025 (ABNT, 2001), which include as one of the requirements, the calculation of uncertainty in essays results. It is of common knowledge that estimating uncertainty in essays using organisms, such as animal and vegetal species, is difficult, preventing from meeting that requirement in the standard. The paper shows the calculation of uncertainties in influences quantities in these essays as a tool to allow validating the measuring process, by using the essays performed by Rhodia Environmental Impact Analysis Laboratory and IPEN Ecotoxicology Laboratory as examples.
\end{abstract}

Key words: Uncertainty, influence quantities, biological essays

\section{INTRODUCTION}

ABNT NBR ISO/IEC 17025 Standard (ABNT, 2001) has been specifically developed for essays and calibration laboratories willing to introduce a quality system. It establishes mechanisms to foster reliability of essays performed, showing that the laboratories operate in conformity with the requirements established by the standard, certifying, thus, technical competence upon essays performance.

In Brazil, specifically in the environmental area, a large gap is observed in the performance of essays where quality systems are adopted. Chemical and biological analysis suitability, including ecotoxicological essays, used in environmental studies in conformity with ABNT NBR ISO/IEC 17025 (2001) have been allowing to expand and strengthen the infrastructure of technological services performed by service-rendering laboratories.

\section{INFLUENCE QUANTITIES UNCERTAINTY}

Organisms behaviors depends highly on environmental conditions in the laboratory, i.e., the influence quantities in the test-system, bearing in mind that, in the International Metrology Vocabulary (INMETRO, 1995), these are defined as "quantities which are not the measurand, but affect the result of its measurement."

In ecotoxicological essays with algae and microcrustaceans, parameters as temperature, $\mathrm{pH}$, dissolved oxygen, hardness and luminosity, may

\footnotetext{
* Author for correspondence
} 
be considered influence quantities. International and national standards establish intervals for these parameters, which must be followed upon essays' performance. Table 1 shows some examples.

This study proposes assessing the uncertainties about these influence quantities, in such a way that, by comparing these uncertainties to the regulatory tolerances, it is possible to validate the measurement process for these quantities.

\section{Uncertainties calculation}

Influence quantities uncertainties calculation is performed exactly in the same way as it is for the result from an analytical measurement, following
EURACHEM/CITAC Guide and Guide to the Expression of Uncertainty in Measurement (EURACHEM/CITAC, 2002; INMETRO/ABNT, 1998].

The following are consecutive steps for calculation:

1. Measurand specification, in this case, the influence quantity;

2. Identification of uncertainty sources, based on Ishikawa Diagram;

3. Quantification of uncertainty components;

4. Calculation of combined uncertainty;

5. Calculation of expanded uncertainty.

Table 1 - Examples of Influence Quantities established in OECD (1984, 1984a) and ABNT (1992, 2004) standards for ecotoxicological assays with algae and microcrustacean (Daphnia).

\begin{tabular}{l|l|l}
\hline \multicolumn{1}{c}{ Anfluence Quantity / Standard } & \multicolumn{1}{c}{ OECD } & \multicolumn{1}{c}{ ABNT } \\
\hline Temperature & $23^{\circ} \mathrm{C}( \pm 2)$ & $24^{\circ} \mathrm{C}( \pm 2)$ \\
Luminosity & $8000( \pm 20 \%)$ & $5000( \pm 10 \%)$ \\
\hline \multicolumn{2}{l}{ MICROCRUSTACEAN $($ Daphnia $)$} \\
\hline Temperature & $20^{\circ} \mathrm{C}( \pm 1)$ \\
Oxygen & $18-22^{\circ} \mathrm{C}( \pm 1)^{*}$ & $1 \mathrm{mg} / \mathrm{L}$ \\
\hline
\end{tabular}

(*) from the selected temperature between 18 and $22^{\circ} \mathrm{C}$ on, $\mathrm{a} \pm 1^{\circ} \mathrm{C}$ variation is acceptable.

\section{Instrumentation}

Table 2 shows the instrumentation used at Rhodia and IPEN Laboratories, concerning the influence quantities, which is similar for both laboratories. The only difference concerns temperature and luminosity measurement.

Measurand specification and Identification of uncertainty sources

Measurement procedures are extremely simple. The only sources considered uncertainty sources are the ones concerning the instruments and standards themselves, if any.

An exception is represented by hardness measurement, to which the complexometry method requires further attention upon preparing an Ishikawa diagram. In this case, measurement comprises two different steps, namely: EDTA solution standardization and hardness measurement.

Consequently, Ishikawa Diagram is also twostepwise prepared, and because both steps in the method use the same methods and equipment, caution shall be exercised concerning the resolution of duplications shown in the diagram.

Calculations of expanded uncertainty via quantification of uncertainty components and calculation of combined uncertainty

As in the previous item, the only relatively timeconsuming calculation is the hardness measurement one, which shall be totally based on EURACHEM Guide (EURACHEM/CITAC, 2002).

\section{Instrumentation validation}

The calculated uncertainties are compared to the regulatory tolerances, allowing, thus, the validation of the influence quantity measurement process. 
Table 2 - Instrumentation concerning influence quantities used at RHODIA and IPEN Laboratories.

\begin{tabular}{|c|c|c|}
\hline Influence quantity & RHODIA Laboratory & IPEN Laboratory \\
\hline Temperature & $\begin{array}{l}\text { Multipoint recorder Yokogawa and Probes } \\
\text { PT-100 }\end{array}$ & Thermometers Max/min \\
\hline $\mathrm{pH}$ & $\begin{array}{l}\text { pHmeter Tecnal } \\
\text { TEC-2 }\end{array}$ & pHmeter Orion $420 \mathrm{~A}$ \\
\hline DO* & $\begin{array}{l}\text { Oxymeter } \\
\text { YSI } 550 \text { DO }\end{array}$ & Oxymeter YSI 51000 \\
\hline Cond.** & $\begin{array}{l}\text { Conductivity } \\
\text { meter } \\
\text { Metrohm } 712\end{array}$ & $\begin{array}{l}\text { Conductivity meter } \\
\text { Orion } 250\end{array}$ \\
\hline Hardness & $\begin{array}{l}\text { Complexometry: } \\
\text { Titration with } \\
\text { standardized EDTA solution }\end{array}$ & $\begin{array}{l}\text { Complexometry: Titration with standardized } \\
\text { EDTA solution }\end{array}$ \\
\hline Luminosity & $\begin{array}{l}\text { Luxmeter Minipa } \\
\text { MLM } 1010\end{array}$ & Luxmeter \\
\hline
\end{tabular}

\section{CONCLUSION}

Uncertainties calculation on biological essays influences quantities is quite simple, as shown in the case studied, concerning ecotoxicological essays, as it allows validating the measurement process for these quantities.

Although it is an indirect measurement of the biological essay uncertainty, it ensures that the regulatory standards requirements are met.

Therefore, validation is recommended for influence quantities measurement, by calculating these quantities uncertainty, for laboratories conducting studies in health and environmental areas.

\section{RESUMO}

Devido à necessidade de demonstrar a confiabilidade dos resultados de ensaios biológicos como, por exemplo, nas áreas de saúde e ambiental, laboratórios vêm implementando sistemas da qualidade, em especial a ABNT NBR ISO/IEC 17025 (ABNT, 2001) que inclui como um dos requisitos o cálculo da incerteza dos resultados dos ensaios. É reconhecidamente difícil de estimar a incerteza de ensaios que utilizam organismos, como com espécies animais e vegetais o que impede, consequentemente, o atendimento deste requisito da norma. $\mathrm{O}$ trabalho apresenta o cálculo de incerteza das grandezas de influências nestes ensaios como uma ferramenta que permite validar o processo de medição, utilizando como exemplos aqueles realizados pelos Laboratórios de Análise de Impacto Ambiental da Rhodia e de Ecologia e Ecotoxicologia do IPEN.

\section{REFERENCES}

ABNT (2004), NBR 12713: Ecotoxicologia Aquática. Toxicidade Aguda. Método de ensaio de toxicidade com Daphnia spp. (Crustacea, Cladocera). Rio de Janeiro.

ABNT (2001), NBR ISO/IEC 17025. Rio de Janeiro.

ABNT (1992), NBR 12648: Água - Ensaio de toxicidade com Chlorella vulgaris (Chlorophyceae). Rio de Janeiro.

EURACHEM/CITAC (2002), Determinando a incerteza na medição analítica.

INMETRO (1995), Vocabulário internacional de termos fundamentais e gerais de metrologia. Rio de Janeiro.

INMETRO/ABNT (1998), Guia para a expressão da incerteza de medição. Rio de Janeiro.

OECD (1984), Guidelines for the testing of chemicals. algae growth inibition test. n. 201. Paris.

OECD (1984a), Guidelines for the testing of chemicals. daphnia sp., acute immobilisation test and reproduction test. n. 202. Paris.

Received: July 29, 2005; Revised: September 05, 2005; Accepted: November 22, 2005. 


\section{FOLHA}

EM

BRANCO 